\title{
Mapping the Evolution of Crime Fiction as a Genre: Eighteenth Century to the Contemporary Times
}

\author{
Shrija Srinivasan ${ }^{1}$, Dr Sushila Shekhawat ${ }^{2} \&$ Dr Somdatta Bhattacharya ${ }^{3}$ \\ ${ }^{1}$ Doctoral Candidate, Birla Institute of Technology and Science (BITS) Pilani, Pilani Campus, \\ Vidyavihar, Pilani, Rajasthan:333031, India. ORCID ID: oooo-0002-5517-0088. \\ Email:p201641@@ilani.bits-pilani.ac.in \\ ${ }^{2}$ Associate Professor, Birla Institute of Technology and Science (BITS) Pilani, Pilani \\ Campus, Vidyavihar, Pilani, Rajasthan: 333031, India. ORCID ID: oooo-ooo2-3101-0784. \\ Email: sula@pilani.bits-pilani.ac.in \\ ${ }_{3}^{3}$ Assistant Professor, Indian Institute of Technology (IIT) Kharagpur, Kharagpur, West \\ Bengal: 721302, India. ORCID ID: 00oo-0002-0074-4793. \\ Email: somdatta@hss.iitkgp.ac.in
}

\begin{abstract}
A mystery story which focuses on a crime and the investigation of that crime is commonly understood as a crime fiction narrative. Its ability to excite the readers, challenge their rational abilities and involve them in the gradual unravelling of the mystery is what makes crime fiction a huge success. With innumerable critical works, scholarly study and continued relevance, crime fiction has entered the canon of literature. A genre that closely reflects the socio-political, historical and cultural aspects of the society, it has gradually acquired a significant role both in critiquing the social order and at the same time for documenting history through its gradual evolution and development. This paper attempts to map the evolution of crime fiction from the eighteenth century to the contemporary times. In doing so, the paper aims to study how social changes impact literary traditions. This study also aims to establish the relevance of crime fiction as a literary genre as it evolves into multiple sub-genres, structures itself into specific rules and regulations and metamorphosises into extra-literary forms.
\end{abstract}

Keywords: crime fiction, society, history, evolution, literature

\section{Introduction}

Be it films, television series, novels or short stories, the genre of crime fiction has certainly been widely consumed by the masses across the years. From the written narratives of Doyle, Christie or Fleming, to their multiple adaptions in the cinematic space, crime fiction, has also expanded into OTT platforms and various web series in the internet era. True crime documentaries such as Forensic Files (1996-1999) are revived through media streaming on internet platforms. The genre is thus both current and relevant. However, although popular, has it been recognised as a serious genre? Does crime fiction qualify to be a part of the literary canon?

(c) AesthetixMS 2020. This Open Access article is published under a Creative Commons Attribution Non-Commercial 4.0 International License (http://creativecommons.org/licenses/by-nc/4.o/), which permits non-commercial re-use, distribution, and reproduction in any medium, provided the original work is properly cited. For citation use the DOI. For commercial re-use, please contact editor@rupkatha.com. 
Bradford's “Can Crime Fiction be taken Seriously?" observes that crime fiction has the ability to find order in a society that is usually chaotic. He quotes Margorie Nicholson's The Professor and the Detective (1929): "this form of writing provides refuge from the ongoing modernist fashion for instability and anarchy" (Bradford, 2015, p.117). The ingenious unravelling of crime by a detective, a gripping investigation by a police officer in a procedural, or the thrill of fast-paced action in spy fiction, are elements that have established the 'mass' appeal of this genre. Moreover, as an exuberant genre with multiple sub-genres, crime fiction is worthy of scholarly study that categorises its form, structure, technique and rules. Contemporary scholars such as Scaggs, Bradford and Knight investigate the origins of the genre. They assert that crime fiction has its origins from traditional mystery and puzzle stories such as the One Thousand and One Nights or from stories of Biblical times. However, one can observe that it is difficult to ascertain a definite point of origin. Bradford (2015) argues that while "Oedipus might be regarded as a precursor to the modern detective" (p.1), the genre in a broad sense developed within British and European space through the prison narratives, significantly, the experiences at Newgate Prison situated in the City of London. J.C. Kinkley (1993), on the other hand, asserts that detective fiction appeared in Chinese literature "nearly a millennium before Edgar Allan Poe" (p.51). However, "[d]espite ancient and modern detective story traditions, the genre was banned during the Mao years (1949 to 1976)" (Kinkley, 1993, p.51). But why was the genre banned in the Chinese tradition? Contrary to Nicholson, it indicates that crime fiction perhaps is not a "refuge" but is instead a reflection of the distorted functioning of society and the errors in the social structure and administration. Hausladen (1996) quotes Ernest Mandell's Delightful Murder: A Social History of the Crime Story (1984) to observe that "the crime story is "intertwined with the history of bourgeois society itself . . . perhaps because bourgeois society is, when all is said and done, a criminal society?" (135)" (p.49). Therefore, one wonders, does the act of gruesome violence, bloodshed, gory details, psychological aberrations, and the violations on the human body, commonly observed in crime fiction narrative, contribute to such censorship? Is this censorship the reason why most writers of crime fiction have used pseudonyms? Frederick Dannay and Manfred Lee use the name Ellery Queen, Williard Huntington Wright is well-known as S. S. Van Dine, C. D. Lewis writes as Nicholas Blake, Ruth Rendell as Barbara Vine, and Hirai Taro writes as Edogawa Ranpo (mimicking Edgar Allan Poe). The above examples, out of many such more, gives us an insight into the complexity and mysteriousness of crime fiction itself, thereby rendering it challenging to trace the origins and evolution of the genre. This paper aims to understand and discuss how crime fiction has been structured as a genre, consisting of multiple sub-genres (such as detective fiction, hard-boiled fiction, police procedurals, spy thrillers, forensic and legal drama, and so on), and how it continues to evolve mirroring the socio-political and cultural circumstances.

\section{Methodology:}

This paper begins with Cesare Beccaria's "An Essay on Crime and Punishment" (1764) and Jeremy Bentham's "Cases Unmeet for Punishment" (1789) that question the legal norms in the society and moves on to critical works on crime fiction and its subgenres. The critical works cited in this paper include Tzvetan Todorov's “The Typology of Detective Fiction" (1966), Julian Symons' Bloody Murder: From the Detective Story to the Crime Novel: A History (1972), George N. Dove's The Police Procedural (1982), and a series of works published consecutively, starting with Martin Priestman edited The Cambridge Companion to Crime Fiction (2003), Stephen Knight's Crime Fiction, 18oo200o: Detection, Death, Diversity (2004), John Scaggs' Crime Fiction: A New Critical Idiom (2005), and Richard Bradford's Crime Fiction: A Very Short Introduction published in 2015. The selection of 
these secondary works represents their significance owing to their thorough and elaborate study around the genre. For the ease of understanding, this paper is divided into three time zones: the Reform period, the period of the two wars and the interim: 1914-1945, and finally, the Postwar period. This paper culminates with police procedurals, a sub-genre of crime fiction paving way for forensic thrillers, legal thrillers and so on.

\section{Reform Period 170os-19oos}

\section{Newgate}

Prior to the 1800 , the European society perceived its judicial system unscientifically. Traditional forms of punishment included the use of torture instruments such as hanging cages, garrotte and guillotine, among others, while witch-hunting was also practised. The English society upheld the "Bloody Code" till the twentieth century. The Newgate prison, situated in the City of London between the Old Bailey and the Newgate Street, ardently followed the Bloody Code. This Code, convicted a felon with death sentence irrespective of the nature of crime committed, be it minor or heinous. Ian A. Bell (2003) in "Eighteenth Century Crime-Writing" explains that the lack of a policing system and investigation method implied that many of these so-called 'convicted felons' were falsely accused. The social hierarchy of classes also enabled the rich to accuse the poor of any crime. Gradually, the overcrowded Newgate prison became infamous for its harsh unhygienic living condition that led to multiple diseases and deaths in clustered prison cells. By the 170os, experiences of these prisoners in the Newgate were recorded by the chaplains and published in the form of "Accounts of lives, crimes, confessions and execution of criminals" (1728). Stephen Knight (2004) says, "The stories offered a moral warning to others and publishing them seems to have been one of the income generating perquisites of the chaplain: they appeared both in cheap pamphlets and also in more expensive small collections" (p.5). By 1773, these accounts were published as the Newgate Calendar, which also included the biographies of the inmates. The Newgate Calendar underwent many revisions and was published consecutively in various versions such as The Malefactor's Register or the Newgate and Tyburn Calendar in 1779, New and Complete Calendar published by William Jackson in 1795, reprinted in 1800, and The Newgate Calendar revised by lawyers Andrew Kapp and William Baldwin (Knight, 2004, p.6). Apart from a record of criminal proceedings, the Newgate Calendar was also a tool for enforcing ideological subordination and for conditioning the masses against criminal activities. These multiple publications and reproductions indicate that these prison narratives were indeed in much demand. These narratives, ultimately, caught the attention of scholars and critics who identified a flawed judicial system and the desperate need of reform. Three significant factors needed strong consideration wherein the first pmphasized on the improved living condition of the prison assuring proper healthcare. The second focussed on the proper trials in cases of conviction, implying the abolition of the Bloody Code and the third, on upholding the ideology that an accused is innocent until proven guilty.

\section{Fieldings, Beccaria and Bentham}

Some of the major reforms originated from the prisoners themselves, who had first-hand experience at Newgate. Those prisoners who were able to escape death penalty included scholars who had the support and influence of wealthy patrons. With shocking revelations of prison conditions and practices, the need for a fair and just judicial system across Europe came into urgent purview. The 
significant proponents advocating reform included the Fielding brother, Cesare Beccaria and Jeremy Bentham.

\section{i. $\quad$ Fieldings}

John and Henry Fielding identified a lack of a proper system that identified and caught criminals. Knight (2004) explains:

The reforms brought about by the Fieldings and their colleagues had two main foci. One was the exchange of information: they realised that magistrates and constables would be in a much better position to arrest criminals if they knew who they were, so they arranged for facts and descriptions to be circulated (Emsley, 1996:221). The Fieldings' other major reform was to have specialists in criminal-catching - and lack of central concern with murder at this time was revealed in calling them 'thief-takers'. Established in 1749, they became known as 'Bow Street Runners' because they were mobile police attached to Bow Street court in central London. . . (p.9-10)

The Bow Street Runners was a progressive step towards a structured system that emphasised on a rationalised process of investigation before identifying a criminal. However, the Bow Street Runners were easily susceptible to corruption and hence they soon disintegrated. In the immediate future we learn how Vidocq brought about a revolution in criminal and forensic investigation and, moreover, how the Peelers stepped into the law enforcement as agents of surveillance. But all these developments are foregrounded by important philosophical and legal concerns. For example, who is a criminal? On what grounds can a person be called a criminal? If and when identified and caught, what kind of punishment should be inflicted upon him or her, and to what degree. These relevant questions were highlighted in the writings of Beccaria and Bentham.

\section{ii. Beccaria}

The Italian scholar Cesare Beccaria (1738-1794) observed the incongruous nature of crime and punishment. He says, "there ought to be a fixed proportion between crimes and punishment" (Beccaria, 1764, p.527). Crime ascends from the "smallest possible injustice done to a private member" to the "dissolution of society" (Beccaria, 1764, p.527). He advocates, "the relations between man and man are relations of equality" (Beccaria, 1764, p.528) and therefore, without proper trial and conviction, an individual should not be condemned. In "An Essay on Crime and Punishment" (1764) he writes:

A cruelty consecrated among most nations by customs is the torture of the accused during his trial, on the pretext of compelling him to confess his crime. .. . A man cannot be called guilty before sentence has been passed on him by a judge, nor can a society deprive him of its protection till it has been decided that he has broken the condition on which it was granted. (Beccaria, p. 530)

Once an individual is convicted of a crime, Beccaria (1764) questions, "Is death penalty really useful and necessary for the security and good for the society?" and "Are torture and torments just, and do they attain the end which the law aims at?" (p.526). The fact that these questions continue to be asked in contemporary society shows the universality and relevance of such concerns. In the Indian context, the death penalty given to the accused in 'Mukesh and another versus State' - or commonly known as the December $16^{\text {th }}, 2012$, Nirbhaya case - is a significant example of recent amendments in the Indian legal system. This case is also reflective of how a criminal act is considered against the "State" or "society" as a whole rather than solely against a "private member" (Beccaria, 1764, p.527).

\section{iii. Bentham}


Jeremy Bentham (1748-1832), an English scholar, outrightly declares punishment as evil. He also replaces the word 'crime' with "mischief" in "Cases Unmeet for Punishment" (1789). He highlights the need to reconsider punishments when they are "inefficacious", "needless" and "unprofitable". He says, punishments are "inefficacious" when (i) the law is "ex post facto", that is, "the penal provision is not established until after the act is done"; and when (ii) the person on whom it is inflicted does not comprehend it, for example, if the person is suffering from "insanity", or "intoxication" (defined here as "temporary insanity") or is an "infant" (Bentham, 178, p.542). Meanwhile, punishments are "needless" when an act of "mischief" is committed for defence or national security. And finally, punishments are "unprofitable" according to Bentham, if it can negatively affect international relations.

The Fieldings, Beccaria and Bentham among other reformers were influential in rationalising judicial ideology and structure. By the early 180os, a scientific spirit was gaining precedence as science and technology strengthened its roots in socio-cultural and judicial practices. From now on, a person will be convicted of a crime based on scientific evidence irrespective of his or her class or position in society. Eugene François Vidocq played a vital role in this and emphasised on criminal forensic investigation.

\section{Vidocq and the Literary Space}

Eugène François Vidocq (1775-1857) was a "criminal who became in 1811 the first chief of the Sûreté, and later started the first modern detective agency, Le Bureau des Renseignements" (Symons, 1972, p.31) in France. Due to his familiarity with the functioning of the criminal world, he proved to be extremely efficient in detecting crimes and capturing criminals. However, since Vidocq and his agents were mostly "ex-convicts", they were never really trusted. According to Symons, rumours suggested that many of the robberies were "engineered" by Vidocq and his agents in order to show the high success rates of crime-solving. Thus, by 1827 , Vidocq had to resign and was replaced by Coco Lacour. However, in 1832, Vidocq resumed office. Although not very successful himself, Vidocq, inspired the establishment of structured policing in the West (such as the formation of the Scotland Yard). His life and Mémoires immensely impacted the literary space and paved the way for early examples of detective fiction, which, as we know, is a popular genre even today. For instance, pioneers of detective fiction writing such as American writer Edgar Allan Poe (1809-1849) and Sir Arthur Conan Doyle were inspired by Vidocq and his life.

Vidocq became a significant motif in the fictional space which featured protagonists who were criminals-turned-investigators. Like Vidocq, these characters could aid and assist investigations due to their familiarity with the underworld and techniques of crime. Popular examples in contemporary media include the American television series, White Collar (2009-2014), or Hannibal Lector from The Silence of the Lambs (1991). According to Knight and Symons, Vidcoq also inspired the "plain-clothes investigator" (Knight, 2004, p.23) who would undergo "physical disguise" (Symons, 1972, p.32) to go undercover for solving cases, such as Sherlock Holmes or Balzac's Vautrin in Père Goriot (1835). In American literature, Poe introduced C. Auguste Dupin who is widely accepted as the first fictional detective figure and a prototype of the "genius detective" (Kayman, 2003, p.50 and Scaggs, 2005, p.39). While more research on fictional and non-fictional records is required to trace early examples of detective figures from geographically diverse contexts, Dupin, based in Europe set a precedence by treating investigation as a scientific enquiry. Following the Enlightenment ideals that instilled scientific and technological vigour, Doyle's Sherlock Holmes acquired symbolic significance of a rational, highly intuitive and extremely meticulous detective 
whose attention to details provide evidences that help catch the criminal. An expert in physical disguises, chemistry and mathematics, Holmes, in A Study in Scarlet (1887) calculates the "height of a man" using "length of his stride" (Doyle, p.26). In the "Red Headed League" (1891), Holmes upholds evidence over conjecture and assumption. He tells Watson, "I shall keep on piling fact upon fact on you until your reason breaks down under them and acknowledges me to be right" (Doyle, 1981, p.20). Reason, logic and rationality took precedence and thus, readers were attracted to mystery narratives that engaged their minds. This engagement with the narrative helped the genre flourish - the readers often tried to solve the crime, identifying themselves with the detective, as they read along the narrative. As it flourished and was taken seriously, the genre also attracted critical interest from scholars. The critics now advocated that the genre required a structure, and that the writers should follow codified rules and regulations.

\section{1914 - 1945}

\section{Detective Fiction and Other Sub-genres}

Van Dine, Ronald Knox, Anthony Berkley and Perez Revertez played a crucial role in imparting a formal structure for narratives of detective fiction. Van Dine's "Twenty Rules of Writing Detective Stories" (1928) and Knox's “Detective Story Decalogue" (1929) established specific basic rules. These rules instructed that detective stories must not have supernatural elements, "the criminal must be someone mentioned in the early part of the story", "the detective must not himself commit the crime" and so on (Scaggs, 2005, p.36-37). Similarly, Berkley emphasised "fair play" in detective fiction writing wherein he advised that "the reader should at least in theory be able to solve the crime at the heart of a story of detection, and for this reason should have access to the same information as the fictional detective" (Scaggs, 2005, p.27). Revertez's "retrograde analysis" advocated "taking a certain position on the board as your starting point and then reconstructing the game backwards in order to work out how it got to that position. A sort of chess in reverse. . . It's all done by induction. You begin with the end result and work backward to the causes" (Scaggs, 2005, p.33). According to George Burton, "all detective fiction is based on two murders of which the first, committed by the murderer, is merely the occasion for the second, in which he is the victim of the pure and unpunishable murderer, the detective," and that "the narrative... superimposes two temporal series: the days of investigation, which begin with the crime, and the days of the drama which lead up to it" (Todorov, 1966, p.44).

From the late nineteenth century to the early twentieth century, both detective fiction and critical works on crime fiction flourished. With the onset of the First World War, however, one observes an ideological and narrative shift in the nature of crime. Writers of crime fiction were now inclined towards depicting violent crimes such as murder instead of "sanitised and bloodless" (Scaggs, 2005, p. 43) crimes such as theft or forgery. Many women writers too emerged successfully as authors of detective fiction. One pertinent example is Agatha Christie who names the title of her Hercule Poirot mystery as "Murder on the Orient Express" (1934) emphasising a heinous crime. At this juncture, blood becomes a crucial trope in crime fiction narratives and hence detectives, with the emerging field of forensic sciences, started using blood and fingerprints as evidence to catch the criminals. In the US, a new sub-genre called the Hard-Boiled mode emerged and started to be known for its extreme crudeness, bloodbaths, gangsterism, gambling and violence. It was a direct reflection post- Prohibition (1919-1933) society and the Great Depression (1929). A few examples of Hard-Boiled fiction with popular private eye detectives include Dashiell Hammett's Maltese Falcon (1930), Raymond Chandler's The Big Sleep (1939) and Mickey Spillane's I, the Jury (1947). Although such works of fiction remained popular among the readers, one finds a significant dip in critca 
interest and publication of critical works in crime fiction between the two wars (1918-1939). Perhaps a consequence of the tense socio-political situations that curbed voices under stringent surveillance and dictatorial rule, the critical works re-emerged post World War II. The three significant works of the twentieth century discussed in this paper include Tzvetan Todorov's "The Typology of Detective Fiction" (1966), Julian Symons' Bloody Murder: From the Detective Story to the Crime Novel: A History (1972) and George N. Dove's The Police Procedural (1982).

\section{Todorov}

Pierre Boileau (1906-1989) and Thomas Narcejac (1908-1998), proficient in locked-room mysteries, argue that "[d]etective fiction cannot be subdivided into kind. It merely offers historically different forms" (Todorov, 1966, p.42). Todorov, however, refutes their argument and contradictorily gives "The Typology of Detective Fiction" (1966). He believes that new genres of literature are created under either of the two conditions: the first is when a work of literature "transgresses" (Todorov, 1966:43) set norms. The second is a case when the uniqueness of a particular work facilitates the creation of a new genre. In his work, Todorov categorises detective fiction as: "Whodunit", "Thriller" or "Série Noir" and "Suspense".

The Whodunit follows a "geometric structure" (Todorov, 1966:4) consisting of two narrative parts. The first part of the narrative focusses on the crime, the second on the investigation. Usually, in the Whodunit, there are two main characters wherein the first is the detective who investigates the crime and the second is the detective's friend who records the events by documenting them in his book. A familiar example is Doyle's Dr Watson who pens his experiences with Sherlock Holmes. Another interesting feature of a Whodunit is how the figure of the detective is always immune. One is reminded of the popular incident when Doyle had to revive Holmes under the pressure of his readers, after the Reichenbach Falls episode in "The Final Problem" (1893). Holmes thus returns in The Hound of Baskervilles (1901-1902).

The Thriller and the Suspense are quite similar to each other in terms of their narrative structure. However, unlike the Whodunit, the detective in a Thriller or Suspense is not immune to threat and harm. Here again, there are two parts to the story wherein one part of the story is responsible for instigating "curiosity" among the readers, and hence moves from effect to cause. For example, the corpse provides evidence that leads the detective to the culprit. The other part of the story ensures that the readers are engrossed in the narrative and thus works from cause to effect, creating the "suspense" or "What will happen next?" (Todorov, 1966, p.47-48). While the Thriller consists of violence, murder, threat and often gangsterism and heists, the Suspense fiction emphasises on a "personal" struggle (Todorov, 1966, p.51). The protagonist in a Suspense, could be a criminal, who is a victim since he has been falsely accused of a crime, and thus must assume the role of a detective trying to prove his innocence. Todorov thus presents the possibility of multiple subgenres under the broader category of crime fiction (or according to him, Detective Fiction) through his typology. However, he also agrees that it is challenging to chronologically trace the evolution of these sub-genres since there are evidences that some of them may have come into existence "simultaneously" (Todorov, 1966 p.52). 


\section{The Post War Period: 1945 -}

\section{Police Procedurals}

While Todorov's “The Typology of Detective Fiction" (1966) classified the sub-genres of detective fiction into Whodunit, Thriller and Suspense, he does not talk about the police procedural. Symons (1972), however, ensures that he delves into the figure of the policeman, who is generally ignored in crime fiction. Historically, in British, the police figure emerged in the form of the Bow Street Runners, and later evolved into the Metropolitan Police Force (Met) in 1829 under Sir Robert Peel. According to Symons, the figure of the police detective was often considered "inefficient" or an authoritative figure "used as the state's arm to suppress reform movements" (Symons, 1972, p. 46), similar to Althusser's "Repressive State Apparatuses". It was thus common for the writers of crime fiction to critique such figures and often at times glorify and romanticise the criminal as a progressive rebel. He argues, "Certain areas of London, as of New York and other big cities, were practically immune from the visits by the police, and the detection of crime was in the hands of Bow Street Runners, who were in effect private detectives operating partly for private reward, and widely thought to be susceptible to bribery" (Symons, 1972, p.45). The Bow Street Runners existed even after the formation of the Metropolitan Police in 1829 , but were finally replaced by the Detective Department in 1842.

Gradually, however, there was a change in the perception brought about through the works of Dickens, Collins and Gaboriau, among others. Dickens' magazine Household Words (1850-1859) portrayed Inspector Field and Inspector Bucket as heroic figures. It transformed the way police officers were represented in narratives. In Charles Felix's The Notting Hill Mystery (1865), officers employed the use of maps to solve crimes. Wilkie Collins' Sergeant Cuff in The Moonstone (1868) was based on "Inspector Jonathan Whicher of the Detective Department" (Symons, 1972, p.51), and the French "hack writer" (Symons, 1972, p.53) Émile Gaboriau's Monsieur Lecoq (1869) showed the police figures as protagonists who were sharp and efficient in their jobs. Symons states that the young policeman "Lecoq is self-seeking and vain, but he is also honest . . . He is the first detective of fiction to make a plaster cast of footprints. .." (Symons, 1972, p.54). Gradually, these writers presented in their narratives how these police officers employed new methods and techniques in their investigation such as use of maps, fingerprint and footprint analysis, and so on. It paved the way for the formalisation of forensic sciences and forensic teams that the police departments would eventually come to depend on. Such narratives also show the gradual emergence of a new subgenre, sprouting from the procedurals, that will solely focus on forensic teams and techniques. A popular example is Kathy Reichs's Temperance Brennan series first published in 1997 (Déjà Dead) promptly adapted into a television series titled Bones (2005-2017), based on forensic anthropology. Other examples include Criminal Minds (2005-2020) based on forensic psychological profiling, and multiple true crime television series such as Forensic Files (1996-2011), Forensic Investigators (20042006), Exhibit A: Secrets of Forensic Science (1997-), Exhibit A (2019) streamed on Netflix, and many more.

The Police Procedural (1982) by George N. Dove is a seminal text for the study of the police procedural sub-genre. Since it is still evolving as a sub-genre, the police procedural is yet to garner the kind of critical attentions that mystery or detective fiction or even the hard-boiled or spy fiction has seen. Dove, in his work, defines the sub-genre, identifies the first police procedural and explicates the characteristics of the sub-genre. According to Dove (1982), the "police procedural" is a mystery story wherein "the mystery is solved by regular police detectives, usually working in teams and using ordinary police routines" (p.1). He clarifies, "[n] ot every story about policeman is a 
procedural" (Dove, 1982, p.2). He excludes those stories where a police officer is a part of the narrative but is not the one who solves the crime. Dove (1982) defines a "procedural" as,

methods of detection employed, the procedures followed by policemen in real life. Where the classic detective solves mysteries through the use of his powers of observation and logical analysis, and the private investigator through his energy and his tough tenacity, the detective in the procedural story does those things ordinarily expected of policemen, like using informants, tailing suspects, and availing himself of the resources of the police laboratory. This qualification almost automatically suggests another one: the policemen in the procedurals almost always works in teams, sharing, the responsibilities and the dangers, and also the credit, of the investigation, with the result that the resolution of the mystery is usually the product of the work of a number of people instead of the achievement of a single protagonist as in the classical formal-problem tale and the hard boiled private eye story. The conventions of popular fiction demand that there be a main-character detective in the procedural, but he or she does not solve the crime without the collaborative efforts of other police. (p.2)

The police procedural adopts elements of realism. The policeman is not a "genius detective" like Sherlock Holmes and therefore, cannot handle the investigation "single-handed(ly)" (Dove, 1982, p.3). The police officer needs aid and assistance from 'his' team and experts from other departments. The police officer is not a flawless character; he is susceptible to making mistakes and is under constant scrutiny by the masses. Moreover, the officer is a public figure and not the private eye/I. According to Dove, the first police procedural was American author Lawrence Treat's Vas in Victim (1945). The sub-genre was made popular with the radio series Dragnet (1951) which later got televised. Many American authors were engaged with this genre. Well known examples include Ed McBain's 87th Precinct series, Hillary Waugh's Last Seen Wearing (1952), Dorothy Uhnak's Christie Opara series and so on. However, it was in Britain that police procedurals flourished, while the American writers favoured the Hard-Boiled mode. Significant British examples include Maurice Procter, J.J. Marric (John Creasy)'s Gideon series (1955-1976), Michael Gilbert and Nicholas Freeling (known for their Van der Valk series) and so on. Dove also mentions police procedurals such as Scottish writer Bill Knox's Deadline for a Dream (1957) set in Glasglow, novels by Swedish writers Maj Sjowall and Per Wahloo, and Poul Ørum's Danish police procedurals.

Dove, in his critical work, observes a transition in the representation of the figure of the cop. Once considered as a "foil" (Dove, 1982, p.44) to the detective, merely "a part of the scenery" (Dove, 1982, p.26), corrupt, and having an "inferior level of education" (Dove, 1982, p.35), the cops have now transformed to become intellectuals such as P.D. James' Adam Dalgliesh who is a "published poet" (Dove, 1982, p.37) and is a "servant and guardian to the public" (Dove, 1982, p.54). "He is the servant of the community that pays him, judges him, and ultimately controls his success or failure as a law officer" (Dove, 1982, p.68). In his chapter titled "The Cop and the System: The Police Sub-Culture I", Dove elaborates on the humane aspects of a police officer who are overburdened with work while often having to fulfil familial roles of being a spouse and a parent, such as Ruth Rendell's Inspector Wexford. Dove writes, "The universal complaint of the procedural is unrelenting overwork, which exacerbates the tedium danger, stress, alienation, anxiety and the rest of the manifestations of the policemen's occupational disease. Unlike private detectives, the police are never off duty. .." (Dove, 1982, p.90). In his latter chapters, Dove explains the techniques used by police officers - such as interrogation and use of informants - in order to solve cases. The procedurals also show the relationship between the officers and the masses, and the challenges and 
pressures of a police officer who is constantly running against time, usually juggling multiple cases at a time.

Dove observes that the sub-genre is gradually evolving with the change in socio-cultural circumstances. A genre that once portrayed only male police officers as detectives started highlighting women officers in significant roles. Earlier when women first entered the police force, Dove (1982) says, they were often assigned duties such as that of "baby-sitting" (monitoring women and small children) and "matron duty" (accessing places where men were not allowed), and were used as "female bait" (to catch criminals like rapists and sex offenders) (p. 156-157). Later, however, women officers were assigned more significant roles. He says, "The first policewoman to be featured in a procedural series was Christie Opara, the central character in the three novels by Dorothy Uhnak": The Bait (1968), The Witness (1969) and The Ledger (1970) (Dove, 1982, p.151). Other examples include Lillian O' Donnell's Norah Mulcahaney in No Business Being a Cop (1978), Nelson De Mille's Pamela York and Ed McBain's Eileen Burke. Dove also observes that the police procedural no longer represented the "while male" protagonist as the norm. The procedurals have transcended not only gender binaries but also ethnicities through works such as John Ball's In the Heat of the Night (1965) which featured Virgil Tibbs, "the only black police detective to have the leading role in procedural series" (Dove, 1982, p.158), or Jewish police officers such as Collin Wilcox's Pete Friedman, or a Hispanic police officer Luis Mendoza created by Dell Shannon.

Police procedurals, therefore, reflected the changing social structure in the post-war society, and they blurred geographical and cultural boundaries to depict cityscapes that were demographically heterogeneous. Commenting on the genre's focus potpourri of multicultural identities in urban centres, Dove (1982) writes, "The main advantage of the urban environment is that it gives the writer infinite opportunity for developing themes involving the anxieties, tensions and frustrations we associate with the city, as well as an almost unlimited choice of characters and situations" (p.238). This possibility of realism within a fictional narrative enables the police procedural to give its readers an authentic portrayal of a society in a certain time. The sub-genre, therefore, has the ability to survive and flourish in contemporary literature, as it evolves and changes along with its social environment.

\section{Conclusion}

From a thorough study of selected seminal narratives including reformative documents and critical and fictional works, it can be concluded that these narratives are a symbolic reflection of society where crime and criminality have always existed in one form or the other, transcending temporal boundaries. From the Biblical stories to twenty-first-century Netflix TV-series such as Sacred Games (2018-), Amazon Prime Video series such as Paatal Lok (2020), or Asur (2020) on Voot, crime fiction has had a long history and continues to remain a popular genre across geographies and cultures. As the genre has a universal quality and a long trajectory of evolution, it becomes challenging to trace its origins. Moreover, the genre falls prey to a tendency on the part of the critics to associate its origins with a Eurocentric point of view. Critical works, thus, assert that crime fiction narratives take shape from the accounts of lives and experiences of the Newgate prisoners. These narratives give rise to the Newgate Novels, often glorifying criminals while critiquing governance and social hierarchy.

The reformation period, which include the works of the Fieldings, Beccaria and Bentham, saw a paradigmatic shift in the understanding of crime and punishment. The gaols were no longer meant to be a space for torture, but instead seen as a space for rehabilitation and reformation. From 
instilling fear into the masses, the new propaganda was to develop a sense of consciousness. However, there was a need to establish a more scientific and reliable method of criminal investigation and a legal and justice system that was capable of measuring and analysing crime and allocating punishment appropriate to the intensity of crime. The figure of the "genius detective" instigated a scientific bend of mind that gradually paved the way for forensic methods and authentic criminal identification. The introduction of the police, be it Fielding's Bow Street Runners (1749) in England or Vidocq's Sûreté (1811) in France, led to a change in social order that reflected in the narratives of those times. Todorov argues that the onset of the First World War and the Great Depression in America lead to the Hard-Boiled mode of writing that mirrored a life of gangsterism and violence. Symons observes an escalation from petty crimes like theft and forgery to gruesome crimes such as rape and murder, resulting in narratives that often sketched gory scenes. The interwar period and the Second World War saw a decline in crime fiction writings and critical works on such narratives. Post-war, in 1945, with Lawrence Treat's V as in Victim, Dove saw the emergence of the police procedural as a genre wherein the police figure was brought into the limelight. Police procedurals, he explains, was a deviation from the popular mystery stories that depicted the fantastic abilities of the detective, exotic locations and tricky investigative techniques. Police procedurals brought the readers back to the real modern world: the slow, the tiresome, the mundane and the chaotic. Unlike the infallible spy-figure, the humane police figure is vulnerable and makes mistakes, and is susceptible to injury and death.

By the turn of the century, contemporary writers such as Priestman, Knight, Scaggs and Bradford attempt to categorise crime fiction and its sub-genres. However, they are unable to make clear delineations. Although their work enables students of crime fiction literature to understand the genre, they also leave multiple questions unanswered such as, the chronology of crime fiction and development of its sub-genres wherein one observes partial overlapping of features. The police procedural, for example, heavily borrows from the narrative characteristics of detective fiction. This inspires further enquiry into the origins of these narrative forms. Does crime fiction descend from gothic fiction? Is Shelley's Victor Frankenstein unravelling the crimes by the "creature" a prototype of the detective figure? Or has crime fiction evolved from mystery puzzle and Biblical stories? Is Oedipus or Caleb Williams the first detective? Which is the first police procedural, Wilkie Collins' Moonstone (1868) or Treat's V as in Victim (1945)? Such questions regarding works on crime and crime fiction from the eighteenth century to the present highlights the diversity in the evolution of crime fiction. It also depicts how it has grown exponentially from textual narratives to multimedia expressions, and hence in thr process undergone a metamorphosis into legal thrillers, forensic procedurals, psychological profiling and so on. Thus, such enquiries cannot ignore the fact that there are no definite answers. In order to solve this mystery, we must assume the figure of the detective ourselves as we explore and study the development of this genre in the national literary traditions of Africa, Middle East, South Asia and the Far East. Then, perhaps, we may move closer to finding the origins of crime fiction within those numerous untranslated works, local scripts and even oral narratives. 


\section{References}

Beccaria, C. (1764). An essay on crime and punishments. The Portable Enlightenment Reader, 525-532. Ed. Isaac Kramnick. USA: Penguin Books, 1995. Print.

Bentham, J. (1789). Cases unmeet for punishment. The Portable Enlightenment Reader, 541-546. Ed. Isaac Kramnick. USA: Penguin Books, 1995. Print.

Bradford, R. (2015).Crime Fiction: A Very Short Introduction. UK: Oxford. Print.

Doyle, A. C. (1887).A Study in Scarlet. Project Gutenberg EBook. 1995.

---, (1891). A scandal in Bohemia. The Adventures of Sherlock Holmes. Project Gutenberg EBook, (2002). 2-18.

---, (1891). The red headed league”. The Adventures of Sherlock Holmes. Project Gutenberg EBook, (2002). 1833.

Dove, G. N. (1982). The Police Procedural. Ohio: Bowling Green University Popular Press. Print.

Hausladen, Gary. (1996). Where the bodies lie: Sense of place and police procedurals. Journal of Cultural Geography, 16(1), 45-63. DOI: 10.1080.08873639609478346.

Kinkley, J. C. (1993). Chinese crime fiction. Society, 30(4), 51-62. DOI: https://doi.org/10.1007/BFo2695237.

Knight, S. (2004).Crime Fiction, 180o-200o: Detection, Death, Diversity. New York: Palgrave Macmillan. Print.

Needless Impatience. (2020, January 24). The Hindu, p. 10.

'Nothing More Urgent': CJI on Delhi Rape Convict's Plea. (2020, January 28). Hindustan Times, p. 1, 4.

Priestman, M. ed. (2003).The Cambridge Companion to Crime Fiction. New York: Cambridge University Press. Print.

Scaggs, J. (2005).Crime Fiction: A New Critical Idiom. Oxon: Routledge. Print.

Symons, J. (1972).Bloody Murder: From the Detective Story to the Crime Novel: A History. England: Penguin Books, 1985. Print.

Todorov, T. (1966). The typology of detective fiction. Poetics of Prose. Print. 